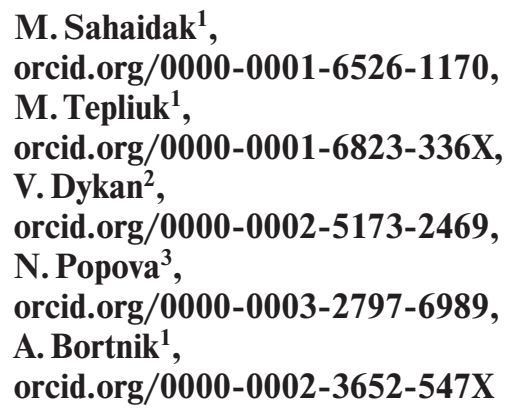

1 - Kyiv National Economic University named after V. Hetman, Kyiv, Ukraine, e-mail: maria_6.11@kneu.edu.ua 2 - Ukrainian State University of Railway Transport, Kharkiv, Ukraine

3 - Kyiv National University of Trade and Economics, Kyiv, Ukraine

\title{
COMPREHENSIVE ASSESSMENT OF INFLUENCE OF THE INNOVATIVE DEVELOPMENT ASYMMETRY ON FUNCTIONING OF THE INDUSTRIAL ENTERPRISE
}

Purpose. To develop and test a methodological approach to assess the impact of the asymmetry of innovative development on the activities of an enterprise based on a combination of statistical, economic, graphical methods of analysis.

Methodology. The study used a set of general and special methods of cognition: logical generalization, qualimetric comparison, taxonomic and index analysis, graphical visualization, scientific abstraction and systematization of data.

Findings. The research established that the current stage of innovative development of economic entities of Ukraine is characterized by asymmetry of the components of the resource portfolio, which in turn actualizes globalization, European integration processes, which emphasizes the importance of the innovative component of development. A comprehensive methodological approach to assess the impact of asymmetry of innovation development on the enterprise, the approbation of which allowed identifying key components of the resource portfolio, characterizing trends and identifying major problems of innovative development of economic entities under the influence of asymmetric fluctuations. An algorithm of use of resource combinations on the basis of asymmetric innovative development of the enterprise is offered.

Originality. In the course of the research a scientific and methodological approach to a comprehensive assessment of the impact of the asymmetry of innovative development on the activities of the enterprise was developed. In contrast to the existing ones, this approach includes: methodological principles of indicative analysis of the effectiveness of the processes of rationalization of the asymmetry of enterprise development based on the expansion of the system of indicators related to the assessment of funding sources. It allows assessing the potential of the chosen strategy of formation of its development resources, recommending methodical approaches to determining the efficiency of resource usage of the enterprise on the basis of comprehensive diagnostics of the resource portfolio,

Practical value. The results of the study can be used by practitioners, scientists, government officials to monitor the asymmetry of innovative development of the enterprise, as well as to improve measures of state regulatory influence on economic entities to enhance innovative development of the country and bring the results of scientific research in line with the current needs of the real sector of the economy.

Keywords: asymmetry of development, resource portfolio, business entities, qualimetry, resource components

Introduction. Today, an important issue of innovation activities is the effective provision and successful management of elements of the enterprise's resource portfolio, and their success in a changing and unpredictable external environment largely depends on the chosen business strategy. The longterm economic growth of a business entity requires a new way of thinking about strategic management.

One of the most important tasks of the modern Ukrainian economy is to ensure the profitability of domestic enterprises by increasing the competitiveness of their products and services, which, in turn, determines the need to take specific steps related to improvement of the efficiency of usage for existing resources of the enterprise, which are limited in some cases, increasing labor productivity, development of domestic production based on the latest scientific and technical developments. Undoubtedly, all of the above should be carried out taking into account the upward global trends in the development of entrepreneurship. This actualizes the problems of the conducted research regarding identification of key factors in the development of domestic enterprises and their adaptability to the conditions of the Fourth Industrial Revolution.

Currently, enterprise management focuses its efforts on development of the competitive advantages of a business based on a portfolio of unique resource sets. However, the growth of their effectiveness depends not only on the availability of re-

(c) Sahaidak M., Tepliuk M., Dykan V., Popova N., Bortnik A., 2020 sources, but also on the ability to transform them into development resources and direct them to achieve their goals.

In the context of the influence of business globalization factors, the openness of resource markets, expanding opportunities and overcoming barriers to their attraction, the impact of effective use of resource portfolio components to ensure competitive advantages significantly increases. Therefore, it is becoming increasingly relevant for enterprises to use the dynamic opportunities of asymmetric innovative development as key principles for ensuring a long-term competitive advantage.

Literature review. Scientific views that are aimed at studying of the problems of innovative development were highlighted in the works by such scientists as: Kotsyuba, Sahaidak et al who believe that "innovative development" is a qualitative change in the structure of connections and the functioning of the system [1, 2], as well as Baharun et al, Didchenko and Kretsul, according to whom, this is the process of transition of a system from one state to another, accompanied by a change in its qualitative and quantitative characteristics [3, 4]. In turn, Didchenko and Kretsul, Danyliuk et al interpret it as an absolute or relative change in indicators that characterize the state of a certain system over time during a certain period [5, 6]. The theoretical basis of the second stage of presentation of the principles of asymmetric innovative development of business entities. Taking into account the concept of dynamic abilities, it is worth noting that the leading role is played by the principle of customer orientation, which is confirmed by the works by 
Khmelevsky [7], Mikhaylyuk [8], Latysheva, et al. [9], Nitsenko, et al. [10], etc. Kotsyuba [2], Piliaiev [11], Awwad [12], and others summarizing the place and role of economic activity of the enterprise, suggests considering it in the following four "contexts": values, factors, organization, effect. Based on all of the above, we believe that modern market conditions of management objectively require the allocation of an additional - fifth component - "asymmetry of innovative development".

Unresolved aspects of the problem. Despite the significant contribution of these scientists, the essence of the definition of "asymmetry of innovative development" and the peculiarities of its manifestation at the enterprise are still insufficiently studied. Issues related to the development and justification of prerequisites for innovative development of enterprises require a deeper theoretical study. Insufficient theoretical justification of these points underlines the relevance of the problems of our scientific research.

The purpose of the article is to develop and test a methodological approach to assess the impact of the asymmetry of innovative development on the activity of an enterprise based on a combination of statistical, economic, and graphical analysis methods.

Methods. In the course of the research a set of general scientific and special methods of cognition was used:

- analysis and synthesis, theoretical generalization and comparison (while studying the economic basis of the conceptual apparatus of "asymmetry of innovative development");

- statistical analysis (when conducting research on the innovative development of the studied business entities in the market);

- methods and techniques of economic analysis, namely Tabular (for presenting calculations and specific research results);

- grouping (when distributing the studied enterprises);

- graphic (for plotting graphs and figures);

- economic and mathematical modeling (to determine the level of influence of the asymmetry of innovative development on the company's activities).

To conduct the study, a comprehensive methodological tool for indicative analysis of the asymmetry of innovative development of an enterprise was developed based on the expansion of the system of indicators, taking into account the specifics of elements and possible combinations of the enterprise's resource portfolio.

Results. In the modern dynamic world of computer technologies, those subjects of market relations achieve success that not only use resources efficiently, but also create unique products and services, since the possession of intellectual, financial, and material resources will at best ensure the company's functioning in the market, but will not ensure a leadership position. To gain or maintain a competitive advantage, an enterprise faces the question of finding "development resources". According to the results of scientific research, it is determined that "development", from an economic point of view, means a certain change in the characteristics of the subject, namely: leads to the transformation of its composition and structure under the influence of changes in external and internal factors that determine the growth processes of qualitative and quantitative increase in the main social and financial and economic parameters of the activity of market relations subjects. It is established that to obtain a competitive advantage, it is necessary not only to combine unique resources, but also to use opportunities caused by the external and internal environment. It is determined that the characteristic of successful functioning of companies is the innovativeness of resource development of enterprises through the prism of allocating resource sets that can be rationally used to realize dynamic abilities and potential opportunities.

To identify indicators and form methodological bases for calculating the indicator of asymmetry of innovative develop- ment of the enterprise's activities, the methodological principles proposed by scientists allow evaluating the totality of key components of the enterprise's resource portfolio. Next, the sets of these components are calculated, and the result obtained indicates the level of financial stability.

Based on the above, to assess the level of rational use of enterprise development resources, we transform the methodology by A. D. Sheremet and R. S. Sayfulin (2000) in the context of introducing indicators that assess accounts payable and inventories into the methodological basis for calculating the indicator of asymmetry of innovative development, namely:

- firstly, we divide inventory into two groups - production inventory and commodity inventory, and long-term liabilities - into medium-term and long-term liabilities;

- secondly, according to the proposed scheme of modification of the methodology of the indicator of assessment of the efficiency of financial resources usage by Kotsyuba [2], we will adapt the methodological foundations of the indicator, and the company's obligations will be divided into short-term, medium-term and long-term

$\begin{array}{rrrr}d(x 11) & d(x 12) & d(x 13) & d(x 14) \\ d(x 21) & d(x 22) & d(x 23) & d(x 24), \\ d(x 31) & d(x 32) & d(x 33) & d(x 34) \\ d(x 41) & d(x 42) & d(x 43) & d(x 44)\end{array}$

where

$$
d(x i j)=1 ; \quad \text { if } \quad x i j \geq 0 ; \quad I=1.5 ; \quad \mathrm{j}=1.5 ; \quad 0 \quad \text { if } x i j<0 .
$$

Noting the calculation formula for each $d(x)$

$$
\begin{gathered}
X 11=F A+L T C+R E+M T C-(I N+S H T C+O F) ; \\
X 12=F A+L T C+R E-(I N+S H T C+O F+M T C) ; \\
X 13=B K+L T C-(I N+S H T C+O F+M T C) ; \\
X 14=F A-(i n+S H T C+O F+V Z) ; \\
X 21=F A+L T C+R E+C 3-(I N+S H T C+M T C) ; \\
X 22=F A+L T C+R E-(I N+S H T C+O F) ; \\
X 23=F A+L T C-(I N+S H T C+O F) ; \\
X 24=F A-(I N+S H T C+O F) ; \\
X 31=F A+L T C+R E+M T C-(I N+S H T C) ; \\
X 32=F A+L T C+R E-(I N+S H T C) ; \\
X 33=F A+L T C-(M T C+S H T C) ; \\
X 34=F A-(I N+S H T C) ; \\
X 41=F A+L T C+R E+M T C-I N ; \\
X 42=F A+L T C+K Z-I N ; \\
X 43=F A+L T C-I N ; \\
X 44=F A-I N,
\end{gathered}
$$

where $F A$ are fixed assets and intangible assets; In - inventories; $R e$ - receivables; $P s$ - production stocks; $O f$ - own funds; $S h t C$ - short-term connections; $M t C$ - medium-term connections; $L t C$ - long-term connections.

Providing significant indicators for each value based on the method of Saati (Table 1).

Methodological bases for assessment of the impact of the asymmetry of innovative development of an enterprise, adapted on the basis of detailing urgency, will be especially relevant for business entities seeking to provide competitive advantages. Therefore, in the process of evaluation of the components of a resource portfolio, it is necessary to take into account the level of intellectual components, namely: human, technological, client, and so on. These components of the intellectual component of the resource portfolio have a significant impact on the balance sheet $[13,14]$. 
Table 1

Methodological bases for assessment of the level of rational use of enterprise development resources

\begin{tabular}{|c|c|c|}
\hline Calculation condition & $\begin{array}{l}\text { Level of } \\
\text { rationality }\end{array}$ & 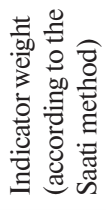 \\
\hline$I N+S H T C+O F+M T C \leq F A$ & absolute & 0.2 \\
\hline $\begin{array}{l}I N+S H T C+O F+M T C \leq F A+L T C, \\
I N+S H T C+M T C \leq F A\end{array}$ & high & 0.1 \\
\hline $\begin{array}{l}I N+S H T C+M T C+D \leq F A+L T C, \\
I N+S H T C+M T C \leq F A+L T C, \\
I N+S H T C \leq M T C\end{array}$ & $\begin{array}{l}\text { above } \\
\text { average }\end{array}$ & 0.1 \\
\hline $\begin{array}{l}I N+S H T C+M T C+O F \leq F A+L T C, \\
I N+S H T C+M T C \leq F A+L T C, \\
I N+S H T C \leq F A+L T C, \\
I N \leq F A\end{array}$ & average & 0.2 \\
\hline $\begin{array}{l}I N+S H T C+M T C-\leq F A+L T C, \\
I N+S H T C \leq F A+L T C+M T C, \\
I N \leq F A+M T C\end{array}$ & $\begin{array}{l}\text { below } \\
\text { average }\end{array}$ & 0.15 \\
\hline $\begin{array}{l}I N+S H T C \leq F A+L T C+M T C, \\
I N \leq F A+L T C+M T C\end{array}$ & pre-crisis & 0.8 \\
\hline$I N \leq F A+L T C+M T C$ & crisis & 0.25 \\
\hline
\end{tabular}

To fully understand the problems and prospects of development of machine-building enterprises, we will analyze the activities of business entities based on the postulates of the proposed methodology of assessment of the asymmetry of innovative development. Accordingly, key factors to ensure innovative development were used, namely: social $(S)$, legal $(L)$, economic $(E)$, political $(P)$, technological $(T)$, innovative $(I)$, Figure.

Taking into account all the conducted economic research, we have established:

Firstly, in conditions of political and economic instability, the functioning of machine-building enterprises falls under the vagueness of linear sets, that is, the probability of a negative impact on the company's activities is quite high.

Secondly, a common problem for all the machine-building enterprises studied is the legal restrictions that do not allow manufacturing of some analogues to foreign products, attracting investment and taking out profitable loans.

Thirdly, barriers to innovative entry to enterprises, limited access to new technologies, and a lack of qualified personnel who can generate new ideas.

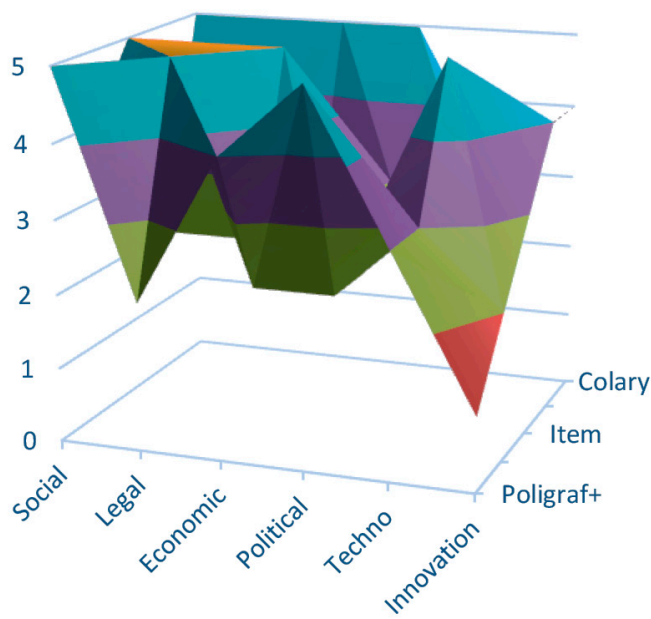

Fig. Graphical display of the asymmetry of innovative development of machine-building enterprises
That is, these indicators are not focused on financial and economic results, which are quantitative, but also determine the need to use qualitative indicators, in prolonged periods, as well as to divide the stocks into production and commodity ones, which is why you should pay attention to the weight of resource components and the balance of the resource portfolio of the enterprise. So, the proposed methodology for assessing the asymmetry of innovative development of business entities' activities can be used by enterprises to build an innovative development strategy with the possibility of leveling errors in linear sets.

In modern market conditions, methods for calculating investment projects do not lose their relevance, where the impact of uncertainty in the market environment, that is errors in linear sets, is quite characteristic and noticeable. Note that when it comes to intellectual components, we consider it appropriate to highlight the indicators of excellence of innovative projects, in particular: net present value; profitability index; discounted payback period; internal rate of return; riskiness of projects, and so on.

At the same time, most modern methods for calculating the feasibility of a project use the EVA (Economic Value Added) model. The corresponding indicator makes it possible to transparently and objectively evaluate investment projects, where it is advisable to include an integral indicator of the asymmetry of innovative development.

The calculation of economic value-added looks like this

$$
E V A=N O P A T-W A C C \cdot I C,
$$

where EVA is Economic Value Added; NOPAT - Net Operating Profit After Tax; WACC - Weighted Average Cost of Capital; $I C$ - Invested Capital.

Summing up the above, we focus on the following: in the professional literature, methodological approaches to assess the effectiveness of development are widely presented; however, taking into account the uncertainty of the modern business environment, we find it appropriate to consider the asymmetry of the distribution of resource components that do not balance the resource portfolio. Based on the analysis of scientific literature, it is determined that the formation of development resources is directly related to the calculation of the feasibility of implementing investment projects, and therefore it is proposed to use the EVA indicator to assess the effectiveness of usage of the components of the resource portfolio.

Based on methodological approaches of analysis of the efficiency of using the components of the enterprise's resource portfolio, we will determine the methodological principles of evaluation of the effectiveness of innovative development of the enterprise with $E R C$ - efficiency of resource portfolio of the company indicator. The volume of their own resources is compared with the total need for implementation of the strategy of formation of resources for enterprise development. If necessary, a decision is made on the use of borrowed resources.

$$
S H V L R=R R P / Z P R R P,
$$

where $C H V L R$ is share of the enterprise's own development resources; $R R P$ - resources for enterprise development; $Z P R R P$ - the general need for resources for enterprise development.

$$
Z P R R P=R R P+P R R P,
$$

where $P R R P$ stands for borrowed resources of enterprise development.

$$
E R C=\operatorname{PrSFRRP} / \sum Z P R R P,
$$

where PrSFRRP is the company's profit from the implementation of the strategy of formation of resources for enterprise development.

Resource components of an enterprise's innovative development can be used both for its internal needs, such as improvement of an existing product or service, or for a more 
global purpose, such as joint ventures to conduct research and develop an innovative product. Statistical data allow us to note a completely natural slowdown in the pace of innovative development, which leads to a decrease in the growth of net income from the provision of services by large companies and the rapid development of medium-sized companies (the growth rate of service provision volumes is on average $25.3 \%$, EBITDA $22.5 \%)$.

At the same time, it is advisable to note that it is biased to diagnose the financial and economic condition of an enterprise solely by financial indicators, as mostly the data presented in the balance sheet do not include components of the intellectual component of the enterprise's resource portfolio. For example, intellectual resources can be considered as one of the factors of asymmetry of innovative development, which are critical for machine-building enterprises and require significant costs for its search and attraction, their management is focused on creating the most favorable working conditions and forming effective motivational mechanisms.

According to the formed indicators, which are critical due to the asymmetry of innovative development of machinebuilding enterprises by the analytical projection, their actual values are systematized in Table 3.

The enterprises studied are differentiated by the share of the intellectual component in the overall structure of the resource portfolio; the discrepancy between these indicators with a critical value was typical only for "Kramar" LLC during 2017-2019. It can be argued that the activity of this enterprise is not aimed at Innovative Development, which is why any asymmetry of manifestation can become utopian for further development, it is aimed exclusively at achieving short-term results and is characterized by the lack of strategic orientations on improvement of the structure of personnel based on the qualification level in order to ensure its stable positions in the future. Despite the high positions of companies in the rating of employers, they do not offset the influence of external factors that are manifested in the offers of high-paid jobs in leading companies in the world, which determines the migration of specialists who want to work in developed countries. So, in the course of the research, methodological principles are proposed for the development and justification of the strategy for the formation of enterprise development resources, the main types of which are defined above. It is established that the list of strategies is indicative, because each enterprise independently chooses and details the strategy in accordance with the goals of its own activities.

Table 2

Positions of machine-building enterprises by rating positions

\begin{tabular}{|c|c|c|c|c|}
\hline Indicator & 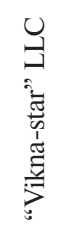 & 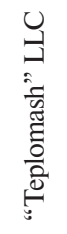 & 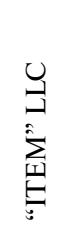 & 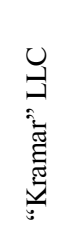 \\
\hline Professional growth opportunities & 0.84 & 0.83 & 0.94 & 0.92 \\
\hline Comfort of working conditions & 0.82 & 0.85 & 0.92 & 0.95 \\
\hline Literacy of Project Management & 0.81 & 0.82 & 0.94 & 0.94 \\
\hline $\begin{array}{l}\text { Completeness of the compensation } \\
\text { package }\end{array}$ & 0.85 & 0.88 & 0.92 & 0.86 \\
\hline Recognition of employee performance & 0.78 & 0.81 & 0.92 & 0.87 \\
\hline $\begin{array}{l}\text { Well-established communication with } \\
\text { management }\end{array}$ & 0.83 & 0.83 & 0.92 & 0.93 \\
\hline Relationships with colleagues & 0.88 & 0.87 & 0.89 & 0.97 \\
\hline $\begin{array}{l}\text { Total score out of } 100 \text { maximum } \\
\text { possible }\end{array}$ & 0.83 & 0.84 & 0.92 & 0.92 \\
\hline
\end{tabular}

Table 3

Actual values of indicators based on the analytical projection, 2017-2019

\begin{tabular}{|c|c|c|c|c|c|}
\hline Indicator & 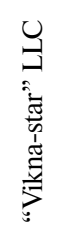 & 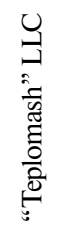 & 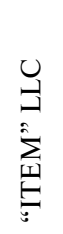 & 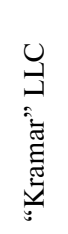 & 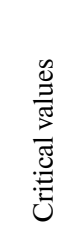 \\
\hline \multicolumn{6}{|c|}{2017} \\
\hline $\begin{array}{l}\text { share of the intellectual } \\
\text { component in the resource } \\
\text { portfolio structure }\end{array}$ & 0.42 & 0.45 & 0.31 & 0.07 & $<0.2$ \\
\hline $\begin{array}{l}\text { turnover rate of employees } \\
\text { who left at their own request }\end{array}$ & 0.18 & 0.17 & 0.28 & 0.17 & $>0.15$ \\
\hline $\begin{array}{l}\text { share of personnel paid by the } \\
\text { client in the total resource } \\
\text { portfolio }\end{array}$ & 0.79 & 0.78 & 0.91 & 0.70 & $<0.8$ \\
\hline $\begin{array}{l}\text { share of personnel costs paid } \\
\text { by the client in total sales of } \\
\text { services }\end{array}$ & 0.06 & 0.07 & 0.21 & 0.24 & $<0.25$ \\
\hline \multicolumn{6}{|c|}{2018} \\
\hline $\begin{array}{l}\text { share of the intellectual } \\
\text { component in the resource } \\
\text { portfolio structure }\end{array}$ & 0.40 & 0.51 & 0.42 & 0.08 & $<0.2$ \\
\hline $\begin{array}{l}\text { turnover rate of employees } \\
\text { who left at their own request }\end{array}$ & 0.17 & 0.17 & 0.21 & 0.19 & $>0.15$ \\
\hline $\begin{array}{l}\text { share of personnel paid by the } \\
\text { client in the total resource } \\
\text { portfolio }\end{array}$ & 0.88 & 0.84 & 0.85 & 0.74 & $<0.8$ \\
\hline $\begin{array}{l}\text { share of personnel costs paid } \\
\text { by the client in total sales of } \\
\text { services }\end{array}$ & 0.06 & 0.06 & 0.15 & 0.22 & $<0.25$ \\
\hline \multicolumn{6}{|c|}{2019} \\
\hline $\begin{array}{l}\text { share of the intellectual } \\
\text { component in the resource } \\
\text { portfolio structure }\end{array}$ & 0.38 & 0.35 & 0.28 & 0.09 & $<0.2$ \\
\hline $\begin{array}{l}\text { turnover rate of employees } \\
\text { who left at their own request }\end{array}$ & 0.17 & 0.23 & 0.24 & 0.21 & $>0.15$ \\
\hline $\begin{array}{l}\text { share of personnel paid by the } \\
\text { client in the total resource } \\
\text { portfolio }\end{array}$ & 0.88 & 0.76 & 0.77 & 0.61 & $<0.8$ \\
\hline $\begin{array}{l}\text { share of personnel costs paid } \\
\text { by the client in total sales of } \\
\text { services }\end{array}$ & 0.07 & 0.09 & 0.24 & 0.33 & $<0.25$ \\
\hline
\end{tabular}

Conclusions. Summing up, we can draw the following conclusions. According to the results of scientific research, it is determined that "development", from an economic point of view, means a certain change in the characteristics of the subject that leads to the transformation of its composition and structure under the influence of changes in external and internal factors that determine the growth processes of qualitative and quantitative increase in the main social and financial and economic parameters of the activity of subjects of market relations.

It is established that to obtain a competitive advantage, it is necessary not only to successfully combine resource combinations, but also to use dynamic opportunities due to the nonlinearity of multiple changes. It is determined that the characteristic of successful functioning of a business entity is innovation and primacy in product development, as well as the desire to rationalize costs and maximize net profit, on the basis of which the methodological basis for assessing the impact of 
asymmetry of innovative development of enterprises, through the prism of intellectual and material resource components, has been improved.

Based on the analysis of the works of scientists, it was determined that the issue of the availability of methodological approaches to assessing the asymmetry of innovative development of an enterprise is insufficiently studied, so in the process of analysis, methodological foundations are proposed for assessing the level of balance in the use of components of the resource portfolio of business entities. It is also established that the formation of innovative development is directly related to the preparation of business projects, the calculation of which is advisable based on net present value indicators. In this regard, it is proposed to apply the EVA indicator and the proposed algorithm for assessing the asymmetry of innovative development, which will give a more complete picture of the strengths and weaknesses of the enterprise's activities.

\section{References.}

1. Kotsyuba, O. S. (2018). Assessment of the economic attractiveness of investment projects in conditions of uncertainty and risk using sensitivity analysis. Business inform, 2(481), 9098.

2. Sahaidak, M., Zavyalova, M., \& Tepliuk, M. (2018). Intelligent resource asymmetries in the logistics management of warehousing in the enterprise. Scientific Journal of Polonia University, 29(4), 51-60. https://doi.org/10.23856/2908.

3. Andriushchenko, K., Tepliuk, M., Sahaidak, M., Kartashov, E., Pivovarov, K., \& Kutashev, I. (2020). Management of the mental resources of the enterprise. International Journal of Management, 11(6), 52-64. $\quad$ https://doi.org/10.34218/ IJM.11.6.2020.005.

4. Baharun, R., Jing Mi, T., Streimikiene, D., Mardani, A., Shakeel, J., \& Nitsenko, V. (2019). Innovation in healthcare performance among private brand's healthcare services in small and medium-sized enterprises (SMEs). Acta Polytechnica Hungarica, 16(5), 151-172. https://doi.org/10.12700/ APH.16.5.2019.5.9.

5. Didchenko, O. I., \& Kretsul, M. M. (2014). Economic assessment of the efficiency of labor resources usage. ZGIA, 1. Retrieved from http://www.zgia.zp.ua/gazeta/evzdia 7 185.pdf.

6. Danyliuk, V., Riepina, I., Shafalyuk, O., Kovylina, M., \& Nitsenko, V. (2020). Functional and investment strategies of technical development of enterprises. Naukovyi Visnyk Natsionalnoho Hirnychoho Universytetu, (3), 115-121. https://doi. org/10.33271/nvngu/2020-3/115.

7. Khmelevsky, S. M. (2014). Changing of the algorithms of financial and economic indicators calculation. Bulletin of Chernihiv State Technological University. Series. Economic Sciences, 2, 179-186.

8. Mikhaylyuk, M.O. (2015). Selection of enterprise's economic activity efficiency development strategy. Bulletin of Khmelnitsky National University, 4, 259-264.

9. Latysheva, O., Rovenska, V., Smyrnova, I., Nitsenko, V., Balezentis, T., \& Streimikiene, D. (2020). Management of the sustainable development of machine-building enterprises: a sustainable development space approach. Journal of Enterprise Information Management. https://doi.org/10.1108/JEIM-12-2019-0419. 10. Nitsenko, V., Kotenko, S., Hanzhurenko, I., Mardani, A., Stashkevych, I., \& Karakai, M. (2020). Mathematical Modeling of Multimodal Transportation Risks. In: Ghazali R., Nawi N., Deris M., \& Abawajy J. (Eds.). Recent Advances on Soft Computing and Data Mining. SCDM 2020. Advances in Intelligent Systems and Computing, (pp. 439-447). Springer, Cham. https://doi.org/10.1007/978-3-030-36056-6 41.

11. Piliaiev, I. (2019). The Value Dichotomy Curse of Ukraine's Modernization: to Break, or not to Be. Ukrainian Policymaker, 5, 68-76. https://doi.org/10.29202/up/5/8.

12. Awwad, M. (2018). Influences of Frege's Predicate Logic on Some Computational Models. Future Human Image, 9, 5-19. https://doi.org/10.29202/fhi/9/1.
13. Kalinichenko, A., Havrysh, V., \& Nitsenko, V. (2019). Alternative Vehicle Fuel Management: Impact on Energy Security Indicators. In: Krakowiak-Bal A., \& Vaverkova M. (Eds.), Infrastructure and Environment, (pp. 367-374). Springer, Cham. https://doi.org/10.1007/978-3-030-16542-0_45.

14. Chukurna, O., Niekrasova, L., Dobrianska, N., Izmaylov, Ya., Shkrabak, I., \& Ingram, K. (2020). Formation of methodical foundations for assessing the innovative development potential of an industrial enterprise. Naukovyi Visnyk Natsionalnoho Hirnychoho Universytetu, (4), 146-151. https://doi. org/10.33271/nvngu/2020-4/146.

\section{Комплексна оцінка впливу асиметрії інноваційного розвитку на функціонування промислового підприємства}

\section{М. Сагайдак ${ }^{1}$, М. Теплюк ${ }^{1}$, В. Дикань ${ }^{2}$, Н. Попова ${ }^{3}$, А. Бортнік ${ }^{1}$}

1 - Київський національний економічний університет імені В. Гетьмана, м. Київ, Україна, e-mail: maria_6.11@ kneu.edu.ua

2 - Український державний університет залізничного транспорту, м. Харків, Україна

3 - Київський національний торговельно-економічний університет, м. Київ, Україна

Мета. Розробити та провести апробацію методичного підходу до оцінювання впливу асиметрії інноваційного розвитку на діяльність підприємства на основі комбінування статистичного, економічного, графічного методів аналізу.

Методика. У ході дослідження використана сукупність загальнонаукових і спеціальних методів пізнання: логічного узагальнення, кваліметричного порівняння, таксономічного та індексного аналізу, графічної візуалізації, наукового абстрагування й систематизації даних.

Результати. У ході наукового дослідження встановлено, що сучасний етап інноваційного розвитку суб'єктів господарювання України характеризується асиметричністю прояву компонентів ресурсного портфеля, що у свою чергу актуалізує глобалізаційні, евроінтеграційні процеси, підкреслює значущість інноваційної компоненти розвитку. Запропоновано комплексний методичний підхід до оцінювання впливу асиметрії інноваційного розвитку на діяльність підприємства, апробація якого дозволила виявити ключові компоненти ресурсного портфеля, охарактеризувати тенденції й виявити основні проблеми інноваційного розвитку суб'єктів господарювання під впливом асиметричних коливань. Запропоновано алгоритм використання ресурсних комбінацій на засадах асиметричного інноваційного розвитку підприємства.

Наукова новизна. У ході дослідження розроблено науково-методичний підхід до комплексного оцінювання впливу асиметрії інноваційного розвитку на діяльність підприємства. На відміну від існуючих, такий підхід включає: методичні засади індикативного аналізу результативності процесів раціоналізації використання асиметрії розвитку підприємства на основі розширення системи індикаторів, пов'язаних з оцінюванням джерел фінансування. Він дозволяє оцінити потенціал застосування обраної стратегії формування ресурсів його розвитку, рекомендувати методичні підходи до визначення ефективності використання ресурсів підприємства на основі комплексної діагностики ресурсного портфеля.

Практична значимість. Результати дослідження можуть бути використані практиками, науковцями, представниками влади для здійснення моніторингу асиметрії 
інноваційного розвитку діяльності підприємства, а також для удосконалення заходів державного регулюючого впливу на економічні суб'єкти задля активізації інноваційного розвитку країни та приведення результатів наукових досліджень у відповідність до актуальних запитів реального сектору економіки.

Ключові слова: асиметрія розвитку, ресурсний портфель, суб'єкти господарювання, кваліметричність, ресурсні компоненти

\section{Комплексная оценка влияния асимметрии инновационного развития на функционирование промышленного предприятия}

\section{M. Сагайдак ${ }^{1}$, M. Теплюк ${ }^{1}$, В. Дикань ${ }^{2}$, Н. Попова ${ }^{3}$, А. Бортник ${ }^{1}$}

1 - Киевский национальный университет имени Вадима Гетьмана, г. Киев, Украина, e-mail: maria_6.11@kneu.edu.ua 2 - Украинский государственный университет железнодорожного транспорта, г. Харьков, Украина

3 - Киевский национальный торгово-экономический университет, г. Киев, Украина

Цель. Разработать и провести апробацию методического подхода к оценке влияния асимметрии инновационного развития на деятельность предприятия на основе комбинирования статистического, экономического, графического методов анализа.

Методика. В ходе исследования использована совокупность общенаучных и специальных методов познания: логического обобщения, квалиметричного сравнения, таксономического и индексного анализа, графической визуализации, научного абстрагирования и систематизации данных.

Результаты. В ходе научного исследования установлено, что современный этап инновационного развития субъектов хозяйствования Украины характеризуется асимметричностью проявления компонентов ресурсного портфеля, что в свою очередь актуализирует глобализа- ционные, евроинтеграционные процессы, подчеркивает значимость инновационной компоненты развития. Предложен комплексный методический подход к оценке влияния асимметрии инновационного развития на деятельность предприятия, апробация которого позволила выявить ключевые компоненты ресурсного портфеля, охарактеризовать тенденции и выявить основные проблемы инновационного развития субъектов хозяйствования под влиянием асимметричных колебаний. Предложен алгоритм использования ресурсных комбинаций на основе асимметричного инновационного развития предприятия.

Научная новизна. В ходе исследования разработан научно-методический подход к комплексной оценке влияния асимметрии инновационного развития на деятельность предприятия. В отличие от существующих, такой подход включает: методические основы индикативного анализа результативности процессов рационализации использования асимметрии развития предприятия на основе расширения системы индикаторов, связанных с оценкой источников финансирования. Он позволяет оценить потенциал применения выбранной стратегии формирования ресурсов его развития, рекомендовать методические подходы к определению эффективности использования ресурсов предприятия на основе комплексной диагностики ресурсного портфеля.

Практическая значимость. Результаты исследования могут быть использованы практиками, учеными, представителями власти для осуществления мониторинга асимметрии инновационного развития деятельности предприятия, а также для совершенствования мер государственного регулирующего воздействия на экономические субъекты для активизации инновационного развития страны и приведения результатов научных исследований в соответствие с актуальными запросами реального сектора экономики.

Ключевые слова: асимметрия развития, ресурсный портфель, суббекты хозяйствования, квалиметричность, ресурсные компоненты

Recommended for publication by O.A. Zinchenko, Doctor of Economic Sciences. The manuscript was submitted 29.05.20. 